\title{
Pathogenicity of Phytophthora pluvialis to Pinus radiata and its relation with red needle cast disease in New Zealand
}

\author{
Margaret Anne Dick ${ }^{\dagger}$, Nari Michelle Williams ${ }^{*}$, Martin Karl-Friedrich Bader, Judy Frances Gardner \\ and Lindsay Stuart Bulman
}

\begin{abstract}
Background: Red needle cast, a new foliage disease of Pinus radiata in New Zealand is described. The disease has been variable in incidence and severity both regionally and in different years. The early symptoms of discrete olive coloured lesions, often with a narrow dark resinous mark or band, were first recognised in winter of 2008 in plantation forests on the eastern coast of the North Island. These lesions develop further to result in rapid needle senescence and premature defoliation. The disease has been termed red needle cast in New Zealand as affected trees have a reddish appearance prior to the casting of the needles. The subsequent four years of monitoring have confirmed that, depending on location, symptoms are first observed in late autumn through late winter. Newly developing spring and summer foliage is seldom affected. Isolation from needles using a Phytophthora-selective medium frequently yielded an unknown species of Phytophthora which was subsequently found to be identical to Phytophthora pluvialis, a species described from Oregon, USA in 2013 where it is not associated with disease. Infection appears to be limited to the needles with no recoveries of Phytophthora pluvialis having been made from the roots, stems or branches. Occasionally a second species of Phytophthora, P. kernoviae, was also recovered from needles with the same symptoms.
\end{abstract}

Methods: Needle symptoms were described in the field from 2008-2012 with isolation onto Phytophthora selective media. Koch's postulates was completed on potted plants and detached needles.

Results: Symptoms were reproduced on both detached needles and potted plants of Pinus radiata when inoculated with zoospore suspensions of Phytophthora pluvialis.

Conclusions: This paper presents evidence that Phytophthora pluvialis is the primary cause of red needle cast in New Zealand.

Keywords: Phytophthora; Phytophthora pluvialis; Red needle cast; Koch's postulates; Forestry; Pinus radiata; Foliar disease

\section{Background}

Originating in coastal California (USA), Pinus radiata (D. Don) is the most widely planted forest tree in the southern hemisphere with extensive plantations in New Zealand, Chile, Australia and South Africa. Pinus radiata represents $90 \%$ of the 1.7 million hectares of the exotic plantation estate in New Zealand (New Zealand Forest Owners Association 2012). These highly productive forests provide a significant contribution to New Zealand's export earnings,

\footnotetext{
* Correspondence: nari.williams@scionresearch.com

${ }^{\dagger}$ Equal contributors

New Zealand Forest Research Institute (Scion), Private Bag 3020, Rotorua 3046, New Zealand
}

accounting for almost $11 \%$ of national exports by value. Forestry exports are currently in the region of \$NZ 4.7 billion per annum (New Zealand Forest Owners Association 2012). Protecting these assets from pests and diseases is of high economic importance and a logistically challenging task.

More than 400 pests and pathogens have been recorded on Pinus radiata worldwide though only a few of these have had a significant effect on growth and productivity (Flux et al. 1993). Of these dothistroma needle blight caused by Dothistroma septosporum (Doroguine) Morelet (Bulman et al. 2013), cyclaneusma needle cast caused by Cyclaneusma minus (Butin) Di Cosmo, Peredo \& Minter (Gadgil 1984) and the wood wasp Sirex noctilio Fabricius

\section{Springer}

(C) 2014 Dick et al.; licensee Springer. This is an Open Access article distributed under the terms of the Creative Commons Attribution License (http://creativecommons.org/licenses/by/2.0), which permits unrestricted use, distribution, and reproduction in any medium, provided the original work is properly cited. 
(Bain et al. 2012) have caused damage to forests at some periods and in some locations in New Zealand. Each of these pests is now subject to active management, so resulting productivity losses are generally at acceptably low levels (Bain et al. 2012; Bulman et al. 2013).

Growth of international trade is increasing the movement of pathogens globally (Santini et al. 2012) with an associated increase in the risk of unintentional introductions of pine pests into New Zealand's exotic forestry plantations. Of particular concern to the local industry is the potential introduction of other, known pests such as Phytophthora pinifolia A. Durán, Gryzenh. \& M.J. Wingf., Fusarium circinatum Nirenberg \& O'Donnell and certain bark beetles, such as species of Dendroctonus and Ips. Although it is important to watch for these known pests, there may be many other potentially harmful organisms not yet known to science, or that are not currently known as pests or pathogens in their home environment (Brasier 2008). In 2007, a serious foliage disease of Pinus radiata caused by an undescribed species of Phytophthora, P. pinifolia, was reported in Chile (Durán et al. 2008). Low levels of genetic diversity within the population of this oomycete indicated that it was a recent introduction to the country (Durán et al. 2010). Its origin remains unknown.

Over the past decade, needle cast events that could not be attributed to a recognised pathogen have been recorded in the New Zealand plantation estate. Disease expression has been highly variable in both incidence and severity, and symptoms have not recurred every year. Regions most commonly affected have been the east coast and the central North Island. Occasionally disease has been noted also in forests in Northland and the Coromandel Peninsula of the North Island and Westland in the South Island. Symptoms included yellowing and browning needles which readily detached from the stem. Cyclaneusma minus was the only recognised pathogen recovered from needles when isolations were made using a general fungal growth medium. However, overall disease characteristics, including the early to midwinter timing of the disease, uniform expression on trees within an affected site, expression on trees younger than 6 years, and formation of discrete lesions within discoloured needles, were not typical of cyclaneusma needle cast.

In June 2005, there was a severe outbreak of these symptoms on a small plateau area in a forest on the East Cape of the North Island. Little disease was reported in the following two years but in early May 2008, during routine forest surveillance, severe needle disease was again reported in the same location. Distinctive needle lesions, different from those associated with known foliage diseases of Pinus radiata in New Zealand, were first observed on green needles in May 2008 in a compartment of 3-year-old trees neighbouring an affected 28-year-old stand, and in a nearby compartment of 14-year-old trees. Isolations made from symptomatic needles using both a general fungal growth medium and a Phytophthora-selective medium ( $\mathrm{P}_{10} \mathrm{ARP}$ agar; Jeffers and Martin, 1986) yielded a species of Phytophthora that bore morphological and genetic similarities to Phytophthora pseudosyringae and Phytophthora nemorosa (known in the USA and in western Europe (Jung et al. 2003; Wickland et al. 2008)) but with sufficient differences to indicate that this was an undescribed species. Subsequently, in 2012, DNA sequence data showed a match with Phytophthora pluvialis (Reeser et al. 2013), a newly described species from Oregon, USA.

Observations of the symptoms, their seasonal development and apparent spread of the disorder gave a strong indication of a likely biotic cause and led to the further investigation of the cause of the disease. The aim of this study was to investigate the role of Phytophthora pluvialis and describe the symptoms and expression associated with the condition.

\section{Methods}

\section{Disease occurrence and symptoms}

Needle symptoms were described and, between 2008 and 2012 , information on the severity and incidence of the condition was gathered from a range of North Island sites. Samples of diseased needles were collected from throughout New Zealand, mainly by trained forest health inspectors who were working on the national forest health surveillance scheme (Kershaw 1989), but also pathologists from the New Zealand Forest Research Institute (Scion), forest owners and farm foresters. All samples were examined in the Scion Forest Protection laboratory. A record of Phytophthora detections from samples consistent with red needle cast was maintained throughout this period. Stands studied ranged from recently established to end-of-rotation plantations and were of varying site types. The development of symptoms within the crown of individual trees was recorded from first appearance of symptoms throughout the seasons.

\section{Isolations from symptomatic tissues}

Needles with lesions were surface sterilised by washing in $70 \%$ ethanol for 30 seconds, rinsed twice in sterile deionised water and blotted dry. Sections from the margins of necrotic lesions were dissected aseptically and plated onto $\mathrm{P}_{10} \mathrm{ARP}$ (pimaricin, ampicillin, rifampicin, pentachloronitrobenzene PCNB) agar as described by Jeffers and Martin (1986) but with $25 \mathrm{mg} \mathrm{L}^{-1}$ PCNB. Plates were incubated at $17^{\circ} \mathrm{C}$ in the dark for up to 14 days. Emerging isolates were sub-cultured onto carrot agar (Erwin and Ribeiro 1996) and grown at $17^{\circ} \mathrm{C}$.

Phytophthora spp. isolates were provisionally identified from morphological features. Colony characteristics on carrot agar and malt extract agar were recorded and the maximum temperature for colony growth determined (Erwin and Ribeiro 1996). Oogonia formed on carrot agar at $17^{\circ} \mathrm{C}$ were measured. Sporangia and hyphal 
swellings were induced by sub-culturing onto carrot agar for 3-5 days whereupon agar plugs from the leading edge of the colony were placed in sterile pond water to induce development of sporangia. Identification was confirmed by DNA sequence analysis of the ITS1 region of ribosomal DNA and cox spacer aligned to that of the type strain LC-9.2-020508 on Genbank (Accessions KC529657.1 and KC529656.1).

\section{Plant inoculations}

The pathogenicity of Phytophthora pluvialis was evaluated on both potted Pinus radiata and with detached needle assays.

\section{Zoospore production}

Zoospore inoculum was prepared by growing isolates on carrot agar at $17^{\circ} \mathrm{C}$ for 3 days. Plugs of agar and mycelium were taken from the leading edge of the colonies, flooded with clarified carrot broth (Erwin and Ribeiro 1996) and incubated for 3 days at $17^{\circ} \mathrm{C}$. The resulting mycelial mats were rinsed thoroughly three times with sterile deionised water, drained and flooded with sterile pond water. These were incubated in the dark for a further 3 days before zoospore release was induced by coldshocking the cultures at $4^{\circ} \mathrm{C}$ in the dark for 45 minutes followed by exposure at room temperature $\left(21-22^{\circ} \mathrm{C}\right)$. Zoospore release was further encouraged by placing cultures on a light box if required. Zoospore concentrations were determined using a haemocytometer and standardised to $1 \times 10^{4}$ zoospores per $\mathrm{mL}$. Zoospore suspensions were used within two hours of preparation.

\section{Detached needle assay}

Needle fascicles were collected from grafted plants of Pinus radiata representing eight different clones. Needles were gently removed from the stem ensuring the papery fascicle sheath at the base of the fascicle remained intact. Forty fascicles were collected from each clone, thirty for treatment with zoospore suspensions of three isolates of Phytophthora pluvialis (10 fascicles per isolate, per clone) and ten for treatment with the sterile pond water in which the zoospores were suspended. The origin of the isolates is given in Table 1 . Needles were placed vertically, fascicle end down, to a depth of $5 \mathrm{~cm}$ in the respective zoospore suspension for a period of 24 hours, laid in trays on moistened paper towels and incubated on a sealed tray at $17^{\circ} \mathrm{C}$ with a 14 hour day/10 hour night period for 14 days. Needles were examined for lesion formation at four-day intervals. After 14 days, needles were assessed for the presence or absence of lesions characteristic of the early symptoms of the disorder (olive-coloured discolouration and black bands or marks). Symptomatic needles were surface sterilised, placed onto $\mathrm{P}_{10} \mathrm{ARP}$ medium and incubated at $17^{\circ} \mathrm{C}$ in the dark. Phytophthora colonies from the needles were
Table 1 Origin of Phytophthora pluvialis isolates used for inoculations of Pinus radiata

\begin{tabular}{lll}
\hline Isolate no. & Date collected & Location \\
\hline NZFS 3613 & $26 / 5 / 2011$ & Turangakuma, Taupo Region \\
NZFS 3713 & $23 / 5 / 2012$ & Wharerata, Gisborne Region \\
NZFS 3717 & $10 / 4 / 2012$ & Wharerata, Gisborne Region \\
NZFS 3719 & $1 / 8 / 2012$ & Ngakuru, Bay of Plenty Region \\
\hline
\end{tabular}

subcultured and identified to species using morphological methods and representative isolates confirmed by DNA sequence analysis.

\section{Inoculation of potted plants}

Pathogenicity tests were carried out using three isolates of Phytophthora pluvialis (Table 1) and four clones of Pinus radiata. An equal number of controls (sterile pond water) were applied to each host clone. The clones were sourced from the current breeding programme of radiata pine and were supplied by the Radiata Pine Breeding Company (Rotorua, New Zealand) as grafted plants. These represented a physiological age of approximately 8 years (Ruth McConnochie pers. com.). Inoculations were performed in a randomised split plot design with three ramets of each clone. Individual trees represented independent plots on which three replicate inoculation tubes were applied per isolate. Individual inoculations were performed on three fascicles each containing three needles resulting in a total of 324 inoculated needles across the trial.

Three adjacent needle fascicles were inserted into a $15 \mathrm{~mL}$ Falcon tube containing $15 \mathrm{~mL}$ of freshly prepared zoospore suspension with no more than one inoculation per twig of needles to avoid cross contamination between inoculation points. The tubes were suspended from the twig or branch so that the whole needle was immersed for 18 hours before removal. After removal of the inoculum solution the empty Falcon tubes were replaced to mark the treated fascicles. Inoculations took place in a controlled environment of $17^{\circ} \mathrm{C}, 65 \%$ relative humidity with a 14/10 hour light/dark period. Fourteen days after inoculation, all treated fascicles were removed from the plants and the needles (three per fascicle) separated from the fascicle sheath. Needles were assessed individually for lesion formation (present/absent) and plated on $\mathrm{P}_{10} \mathrm{ARP}$ medium after surface sterilisation (30 seconds in 70\% ethanol and two washes in sterile deionised water). Asymptomatic and symptomatic needles were plated. Plates were incubated at $17^{\circ} \mathrm{C}$ in the dark and examined weekly for formation of Phytophthora spp. colonies for three weeks. Emergent Phytophthora spp. colonies were subcultured and identified to species using morphological criteria, as previously described. Representative isolates from each treatment were sequenced for further confirmation. 


\section{Statistical analysis}

The detached needle assay was analysed using a generalised linear mixed model (GLMM) with binomial errors (R-package lme4) testing for differences in the proportion of needle lesions between the uninoculated control and the samples inoculated with 3 isolates of Phytophthora pluvialis. 'Host clone identity' was modelled as a random effect.

The potted plant study was laid out as a split-plot design comprising 3 blocks. A GLMM with Poisson errors (R-package lme4) was used to test for differences in the number of lesioned needles per fascicle between the control treatment and 3 pathogen isolates in dependence on host clone identity. Hence, the fixed structure of the model contained 'pathogen isolate' (factor with 4 levels: zero control, Phytophthora pluvialis isolates 3613, 3713, 3719) and 'host clone' (factor with 4 levels: A, B, C, D) and their interaction as explanatory variables. 'Fascicle identity' nested in 'block' were modelled as random effects.

In both models, the occurrence of the Hauck-Donner effect or the analogue thereof in case of the Poisson model (i.e. fitted probabilities close to zero in the control treatment leading to very large standard errors) made the standard errors of the parameter estimates and hence the associated P-values unreliable. Therefore, the significance of the model terms was assessed via backwards selection using likelihood ratio tests (Zuur et al. 2009). Multiple comparisons were performed using likelihood ratio tests to compare nested models, one which allowed separate parameter estimates for all pathogen isolate and host clone levels, respectively, against a series of models in which two factor levels were pooled in turn. To account for multiple testing, the resulting $P$-values were adjusted using the Benjamini and Hochberg (1995) method, that controls false discovery rate (i.e. the expected proportion of false discoveries among the rejected hypotheses). Plots of the deviance residuals versus fitted values and against each of the explanatory variables were used for model validation. All statistical analyses were carried out using $\mathrm{R}$ software version 2.15.2 (R Core Team 2012).

\section{Results}

\section{Disease occurrence and symptoms}

Red needle cast was found to be most common on trees over four years old and most severe on trees over ten years old. Younger trees and seedlings have shown symptoms of infection but usually only when growing in close association with heavily infected older stands.

First obvious symptoms on needles are generally a pale-olive or khaki coloured lesion of varying length frequently with a distinct dark resinous mark which often expresses as a narrow lateral band within the lesion
(Figure 1). Very close inspection of apparently asymptomatic needles may reveal black bands on the green needle. These appear prior to the formation of the faded olive lesion (Figure 2) within which black bands may or may not be observed. Lesions may occur on any part of the needle but are more abundant at the base next to the fascicle sheath than on distal parts of the blade (Figure 3). Lesions expand along the needle turning yellow and then brown with trees developing an overall reddish appearance (Figures 4 and 5). Following infection, needles quickly senesce with entire fascicles being readily cast from the twig, often before the needle blade is completely necrotic and often when only one or two of the three needles within the fascicle are affected. Successive cycles of infection and casting continue throughout periods of persistently damp conditions giving the affected part of the crown an ongoing reddish appearance from symptom initiation in autumn through to early spring. Pinus radiata trees showing characteristic disease symptoms are shown in Figure 6. The timing of symptom initiation varies depending on localised climatic conditions. By late spring heavily affected trees may be fully defoliated, though in many stands infection is not severe and only needles in the lower crown of the trees are symptomatic (Figure 7). These symptoms gave rise to the name "red needle cast". New season needle growth is generally not affected and new needle infections seldom occur during the summer months. As a result, trees appear to return to health during summer with the fresh flush of needles showing few signs of disease. In a few sites of limited extent where severe defoliation has occurred in successive years the new season needles may be stunted and chlorotic.

Under continually moist conditions sporangia may be observed with the aid of a microscope forming in clusters

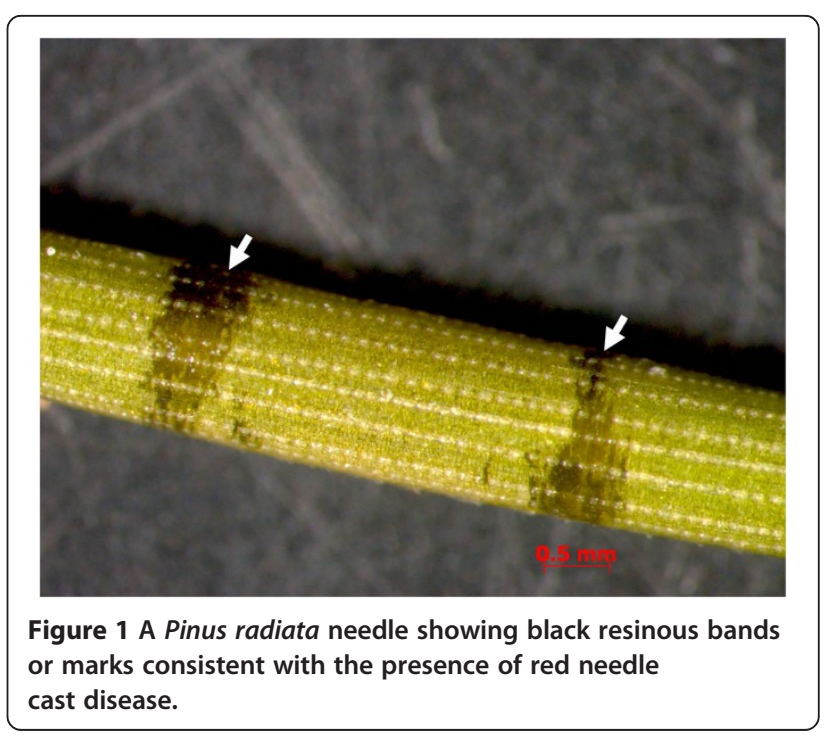




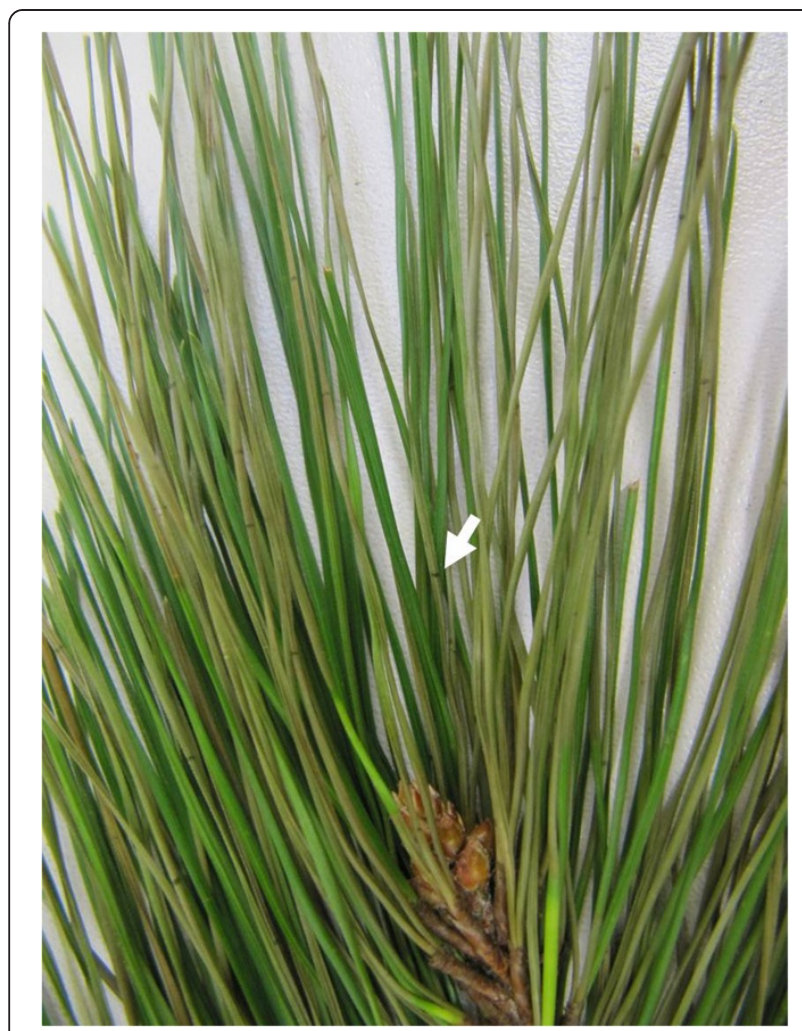

Figure 2 A Pinus radiata needle showing faded olive- or khakicoloured lesions consistent with the presence of red needle cast disease. Arrow shows resinous bands within the extended olive lesion.

around the stomata on both surfaces of the needle. Observations on field samples indicate these are transient and produced during periods of prolonged leaf wetness. Sporangia can be found near the lesion margin and in advance of visible lesions (Figure 8). These observations were confirmed by microscopic observation and isolation of sporangial masses on selective $\mathrm{P}_{10} \mathrm{ARP}$ agar. Infection appears to be confined to the needles; twig necrosis, stem cankers,

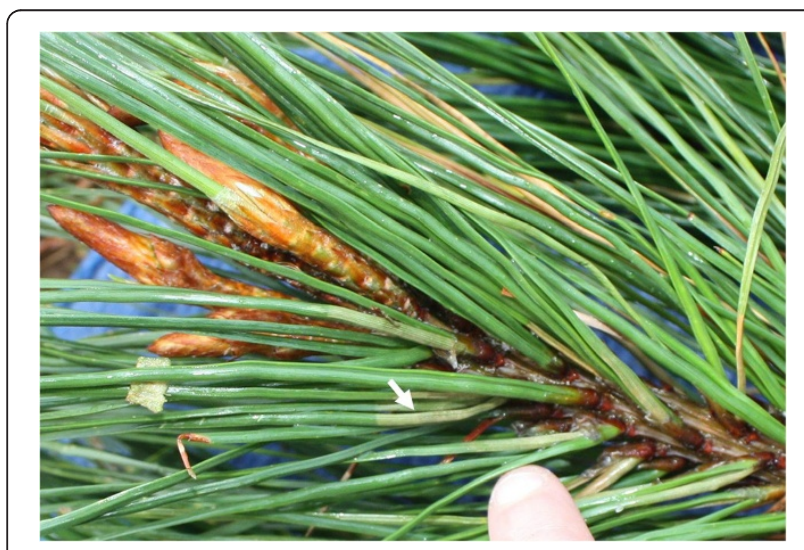

Figure 3 Lesions consistent with the presence of red needle cast disease are more abundant at the base of Pinus raiata needles as indicated by the arrow.

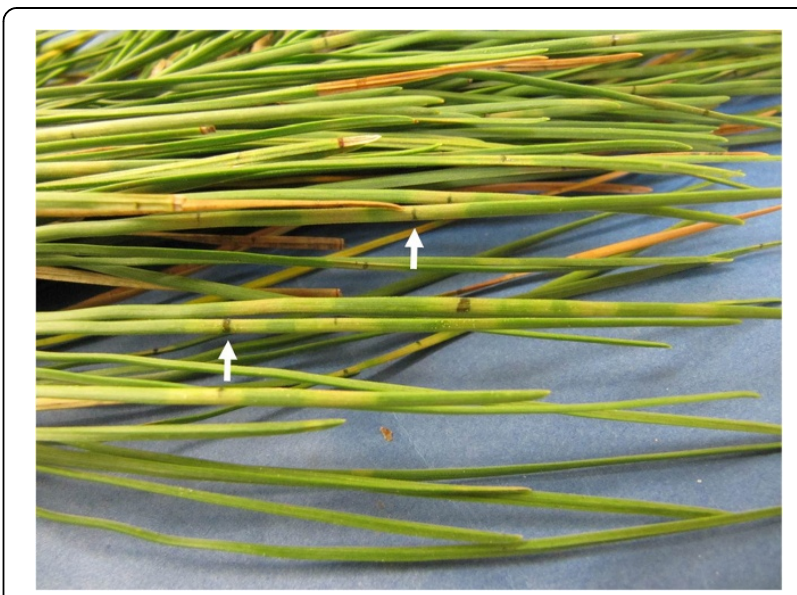

Figure 4 Pinus radiata needles showing colour changes following infection with red needle cast disease. The tissues around the initial infection at the base or along the needle senesce, and change yellow and then brown as indicated by the arrows before the needles cast.

twig, branch and stem resin bleeding or lesion/canker formation has not been observed.

\section{Isolations from symptomatic tissues}

Typically symptomatic needles were collected by forest health inspectors, pathologists from the New Zealand Forest Research Institute (Scion), forest owners and farm foresters from field trials and trees showing signs of the disease. Recovery of Phytophthora pluvialis from these samples was variable with higher rates of isolation from samples with fresh lesions. Isolation results from 543 independent collections between April 2008 and October 2012 were collated. Of these, the majority of samples were collected from the East Cape of the North Island (172) and from central North Island (198). Phytophthora pluvialis was most frequently recovered from samples originating from those two regions and least frequently from the

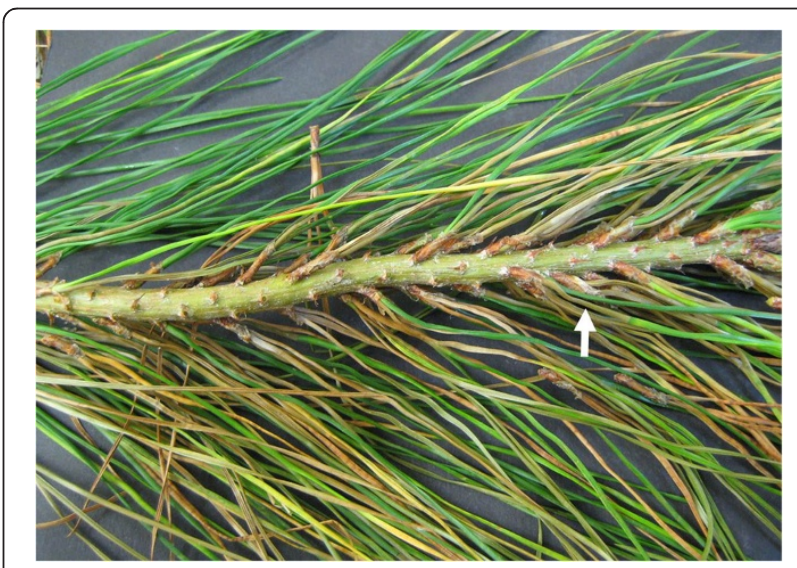

Figure 5 Typical red needle cast symptoms along a twig. Lesions begin at the base of the needle which subsequently turns brown and is cast from the twig. 


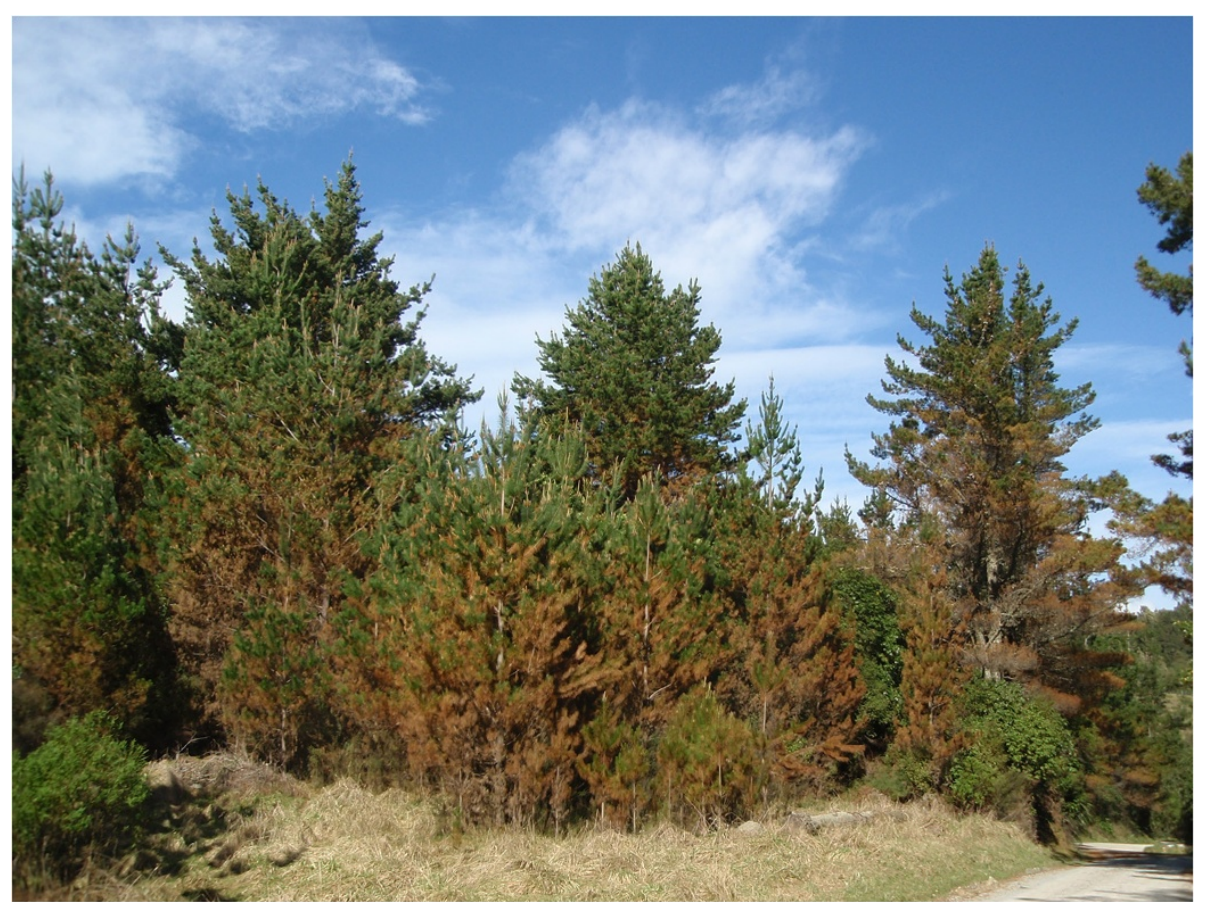

Figure 6 A stand of Pinus radiata trees affected by red needle cast disease. Note the reddish appearance of affected trees prior to needle drop.

southern North Island and the upper South Island (Table 2). Phytophthora pluvialis was isolated from $27 \%$ of needles that had symptoms considered characteristic of the disease. Most collections were made in winter and spring when inoculum levels and disease severity were highest and isolation from lesion material was greatest. Phytophthora pluvialis was isolated rarely from needles during summer (Table 3) despite the occasional presence of characteristic lesions.

A further species of Phytophthora, P. kernoviae Brasier \& Beales, was also recovered, from symptomatic needles, though less frequently (6\%). Phytophthora kernoviae was most frequently detected in samples from the northern North Island (Table 3). In the northern North Island the disease is associated with greater needle retention than in other regions although symptom expression extends further into spring than in areas further south.

From 2011 onwards, serological kits that indicate the presence of a Phytophthora sp. (genus only) were used to aid diagnosis. Of the 177 samples tested over that period, 100 (57\%) were positive for Phytophthora spp. and of those 52 were also confirmed by isolation and morphological identification. Only Phytophthora pluvialis and Phytophthora kernoviae were found.

\section{Plant inoculations}

\section{Detached needle assay}

Many of the inoculated needles (41\%) developed olivecoloured lesions which frequently contained a black resinous band whereas the uninoculated control needles remained free of lesions. The observed lesions were identical to those seen on naturally infected plants during continuously wet periods. The first symptoms were observed 8 days after inoculation. Numbers of symptomatic needles increased rapidly thereafter. To analyse the variation between isolates, results for the different clonal lines were combined with no significant difference observed between the three isolates of Phytophthora pluvialis that were applied (Figure 9). The relationship between clone and isolate was found to be insignificant and no lesions formed on any of the control needles.

\section{Inoculation of potted plants}

Inoculations resulted in lesions similar to those seen on naturally infected plants. These were observed on $35.5 \%$ of inoculated needles with $64.8 \%$ of inoculated fascicles containing at least one needle with a lesion. There was a significant interaction between Phytophthora pluvialis isolates and Pinus radiata host clones $\left(x^{2}=19.3, \mathrm{df}=9\right.$, $P<0.023)$. In host clone $\mathrm{A}$, none of the three tested pathogen isolates produced significantly more lesioned needles per fascicle than the uninoculated control (Figure 10). In host clone B, pathogen isolates 3613 and 3713 produced similarly small numbers of lesioned needles $(<0.5$ per fascicle), but the slightly smaller effect observed in isolate 3613 resulted in an insignificant difference from the control treatment (Figure 10). Isolate 3719, however, caused on average 1.33 lesions per fascicle which differed significantly from the control and isolate 3613, but not 


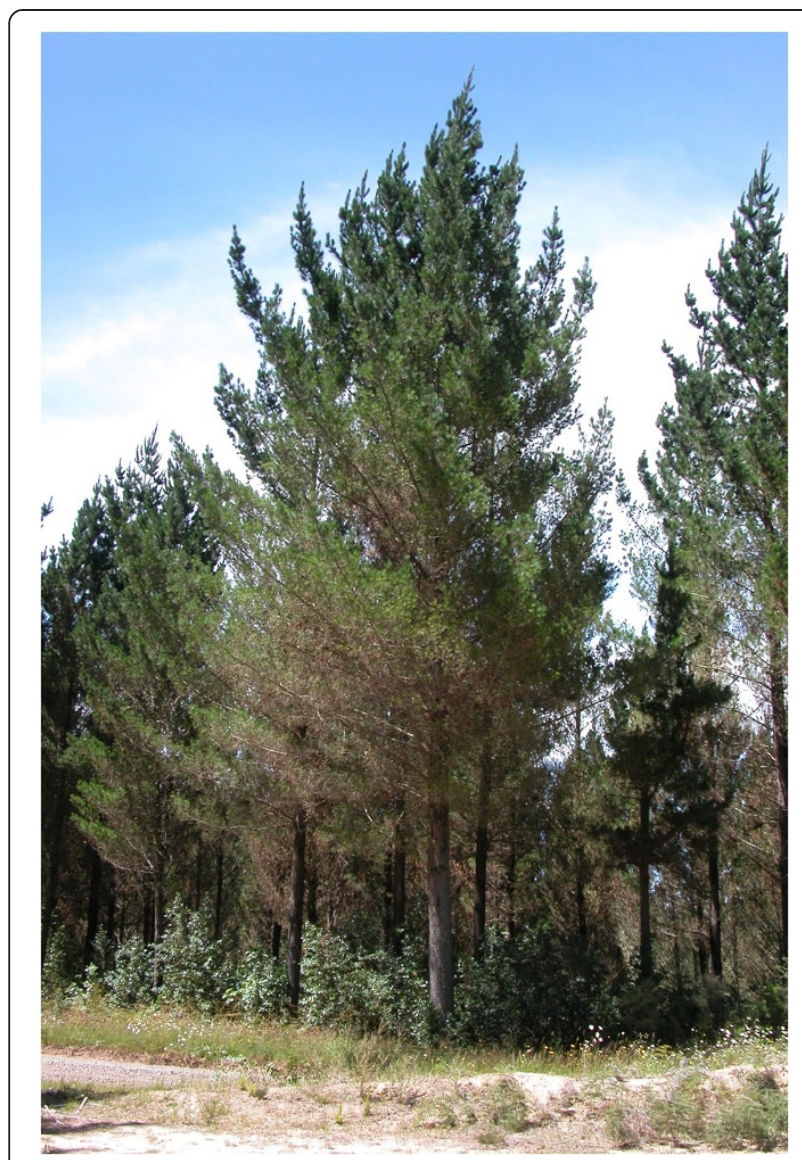

Figure 7 A stand of Pinus radiata trees affected by red needle cast disease. Note that frequently only the lower part of the crown is affected.

from isolate 3713. Clones C and D shared a similar response to Phytophthora pluvialis isolates. In these two host clones, all three pathogen isolates caused significantly more lesions than the uninoculated control, ranging between 1 and 2.5 lesioned needles per fascicle, which,

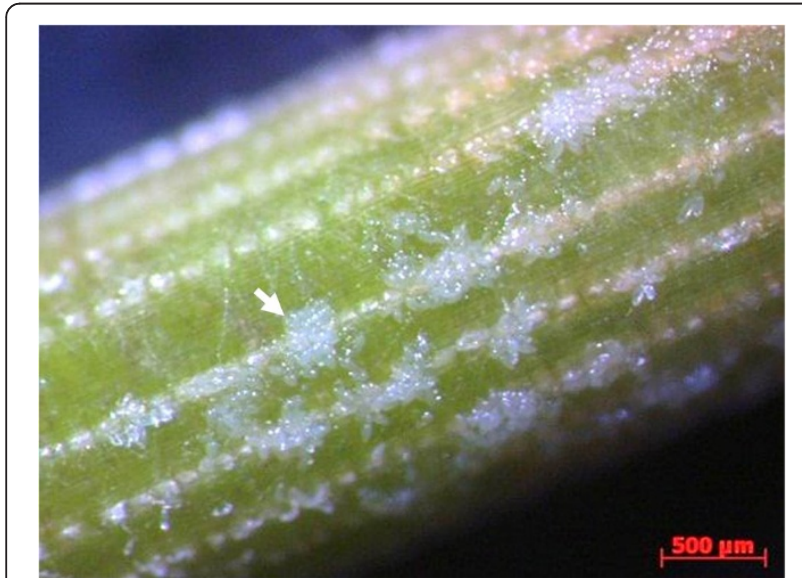

Figure 8 A Pinus radiata needle infected with Phytophthora. Note clusters of sporangia emerging through the stomata on both surfaces of the needle as indicated by the arrow. however, did not differ significantly from each other (Figure 10).

The lesions varied in length, sometimes extending along the whole needle blade. More than one lesion was observed on a number of needles. Black resinous marks were recorded on fewer than $25 \%$ of needles. Short olive-brown lesions were recorded on $4(1.6 \%)$ of the 252 needles in the control treatments. None of these had resinous marks.

Phytophthora pluvialis was reisolated from 64 of the total of 324 inoculated needles (19.8\%), all of which had symptoms of disease. No recoveries were made from asymptomatic tissues. These recoveries were spread across the treatments. No other species of Phytophthora were isolated and there were no recoveries of Phytophthora species from the control treatments.

\section{Discussion}

Red needle cast of Pinus radiata has been most consistently associated with the isolation of Phytophthora pluvialis from infected needles. Controlled inoculation studies, including the reproduction of needle lesions, needle cast and fulfilment of Koch's postulates have provided further evidence that it is the primary cause of red needle cast. However, much remains to be learned about the epidemiology of the disease.

Isolations made from symptomatic trees onto general fungal growth media (such as malt extract agar and potato dextrose agar) have yielded a range of fungi long recognised as Pinus radiata needle associates in New Zealand. These include the known pathogen Cyclaneusma minus (Gadgil 1984) and many saprophytes or secondary pathogens such as Lophodermium spp., Pestalotiopsis spp., Fusarium spp., Phomopsis spp., Strasseria geniculata (Berkeley \& Broome) Hoehnel and Ceuthospora sp. The pattern of recovery of these fungi has not been consistent with location, season or tree age and there has been no indication of a consistent association for any of these with the symptoms of red needle cast.

Isolations using a Phytophthora-selective medium repeatedly yielded cultures of Phytophthora pluvialis, and isolates of this species produced typical disease symptoms in inoculated pine needles. Re-isolation confirmed that Phytophthora pluvialis is the cause of red needle cast in Pinus radiata. Sampling by pathologists targeting fresh lesion material resulted in the isolation of Phytophthora from $76 \%$ of characteristic needle lesions (Hood et al. 2014). Recovery of $P$. pluvialis from symptomatic needles was variable between collections but clearly decreased with time after infection had occurred. These results are consistent with detection of many species within the Phytophthora genus (O'Brien et al. 2009). In Pinus radiata, as with other conifer species in England infected with Phytophthora ramorum, recovery rates from shed 
Table 2 Numbers of samples received ( $n$ ) and diagnostic result (\%) by year and region

\begin{tabular}{|c|c|c|c|c|c|c|}
\hline \multirow[t]{2}{*}{ Samples } & \multicolumn{5}{|l|}{ Year } & \multirow[t]{2}{*}{ Total } \\
\hline & 2008 & 2009 & 2010 & 2011 & 2012 & \\
\hline Northern North Island (n) & 14 & 8 & 6 & 26 & 13 & 67 \\
\hline \multicolumn{7}{|c|}{ Species isolated/identified (\%) } \\
\hline None & 50.0 & 75.0 & 83.3 & 46.2 & 25.0 & 50.0 \\
\hline Phytophthora pluvialis & 50.0 & 12.5 & 0.0 & 11.5 & 33.4 & 22.7 \\
\hline Phytophthora kernoviae & 0.0 & 12.5 & 16.7 & 34.6 & 33.4 & 22.7 \\
\hline Phytophthora sp. & 0.0 & 0.0 & 0.0 & 7.7 & 8.3 & 4.6 \\
\hline Central North Island & 64 & 17 & 19 & 47 & 51 & 198 \\
\hline \multicolumn{7}{|c|}{ Species isolated/identified (\%) } \\
\hline None & 70.3 & 47.1 & 73.7 & 46.8 & 37.3 & 54.5 \\
\hline Phytophthora pluvialis & 28.1 & 52.9 & 15.8 & 38.3 & 35.3 & 33.3 \\
\hline Phytophthora kernoviae & 1.6 & 0.0 & 10.5 & 6.4 & 7.8 & 5.1 \\
\hline Phytophthora sp. & 0.0 & 0.0 & 0.0 & 8.5 & 19.6 & 7.1 \\
\hline East Cape & 41 & 38 & 24 & 45 & 24 & 172 \\
\hline \multicolumn{7}{|c|}{ Species isolated/identified (\%) } \\
\hline None & 51.2 & 81.6 & 58.3 & 53.3 & 41.7 & 58.1 \\
\hline Phytophthora pluvialis & 46.3 & 15.8 & 37.5 & 28.9 & 25.0 & 30.8 \\
\hline Phytophthora kernoviae & 2.4 & 2.6 & 4.2 & 4.4 & 0.0 & 2.9 \\
\hline Phytophthora sp. & 0.0 & 0.0 & 0.0 & 13.3 & 33.3 & 8.1 \\
\hline Southern North Island & 2 & 4 & 6 & 11 & 4 & 27 \\
\hline \multicolumn{7}{|c|}{ Species isolated/identified (\%) } \\
\hline None & 100.0 & 100.0 & 100.0 & 63.6 & 75.0 & 81.5 \\
\hline Phytophthora pluvialis & 0.0 & 0.0 & 0.0 & 0.0 & 25.0 & 3.7 \\
\hline Phytophthora kernoviae & 0.0 & 0.0 & 0.0 & 9.1 & 0.0 & 3.7 \\
\hline Phytophthora sp. & 0.0 & 0.0 & 0.0 & 27.3 & 0.0 & 11.1 \\
\hline Upper South Island & 8 & 8 & 16 & 26 & 21 & 79 \\
\hline \multicolumn{7}{|c|}{ Species isolated/identified (\%) } \\
\hline None & 100.0 & 87.5 & 87.5 & 53.8 & 42.9 & 65.8 \\
\hline Phytophthora pluvialis & 0.0 & 0.0 & 6.3 & 26.9 & 28.6 & 17.7 \\
\hline Phytophthora kernoviae & 0.0 & 12.5 & 6.3 & 0.0 & 4.8 & 3.8 \\
\hline Phytophthora sp. & & & & 19.2 & 23.8 & 12.7 \\
\hline Total (n) & 129 & 75 & 71 & 155 & 113 & 543 \\
\hline
\end{tabular}

Table 3 Numbers of samples received and percentage diagnostic results by season

\begin{tabular}{|c|c|c|c|c|c|}
\hline \multirow{3}{*}{$\begin{array}{l}\text { Samples } \\
\text { Total number }\end{array}$} & \multicolumn{4}{|l|}{ Season } & \multirow{3}{*}{$\begin{array}{l}\text { Tota } \\
543 \\
\end{array}$} \\
\hline & Autumn & Spring & Summer & Winter & \\
\hline & 68 & 208 & 53 & 214 & \\
\hline \multicolumn{6}{|l|}{ Species isolated/identified (\%) } \\
\hline None & 54.4 & 62.5 & 88.7 & 47.2 & 58.0 \\
\hline Phytophthora pluvialis & 26.5 & 23.1 & 9.4 & 36.9 & 27.6 \\
\hline Phytophthora kernoviae & 4.4 & 6.3 & 0.0 & 8.4 & 6.3 \\
\hline Phytophthora sp.* & 14.7 & 8.2 & 1.9 & 7.5 & 8.1 \\
\hline Phytophthora pluvialis/Phytophthora kernoviae & 0.0 & 0.5 & 0.0 & 0.0 & 0.2 \\
\hline
\end{tabular}

*Identified using Agdia ImmunoStrips, negative using traditional techniques. 


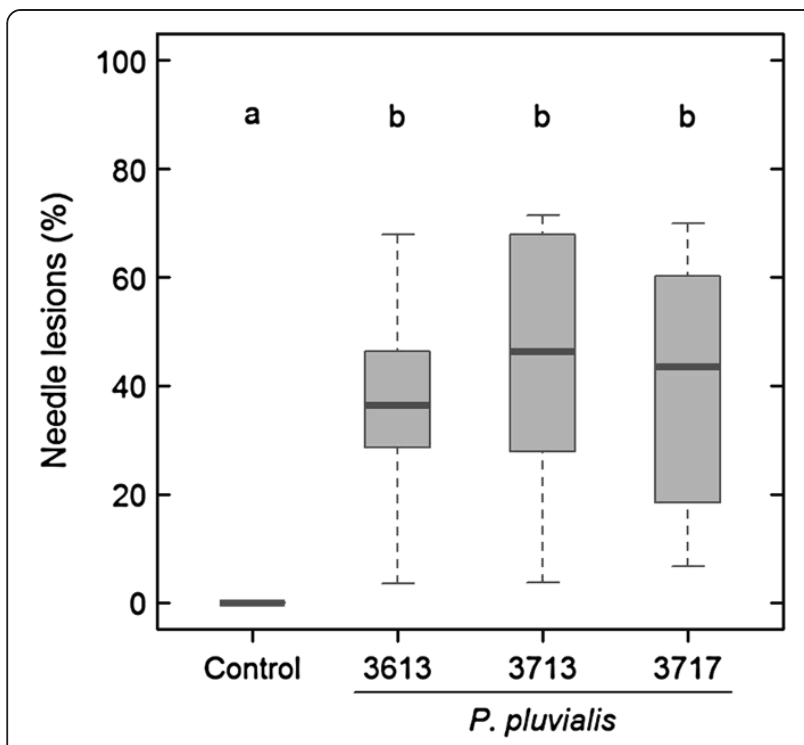

Figure 9 Percentage of lesions recorded from Pinus radiata needles inocluated with 3 Phytophthora pluvialis isolates (NZFS isolates 3613,3713 and 3717 ) compared with an uninoculated control. Boxplots show the median (horizontal bold lines, $n=8$ ), the spread of the data given by the interquantile range between the $25^{\text {th }}$ and the $75^{\text {th }}$ percentile (grey boxes). The 'whiskers' indicated by the dashed lines represent either the maximum/minimum values or 1.5 times the interquantile range of the data, whichever is smaller. Different lower case letters indicate significant differences at $\alpha=0.05$ based on a multiple comparison test.

needles has been observed to be considerably lower than from fresh needle lesions (Brasier and Webber 2010; Forestry Commission 2012).

To complement direct isolation, a range of diagnostic techniques have been employed in the diagnosis of the disease from field material. These include visual examination for the presence of the characteristic needle symptoms, microscopic examination of sporangia on the needles and the use of a serological test kit capable of indicating the presence of Phytophthora species to genus level (Lane et al. 2007). Use of the kits resulted in a significant increase in the number of Phytophthora-positive results, as recovery by isolation does not always occur. In such cases, since October 2012, the test kit material has been used directly for identification to a species level by DNA sequence analysis using species-specific primers (Rebecca McDougal pers. comm. publication in preparation).

In this study, inoculation of Pinus radiata with Phytophthora pluvialis resulted in the reproduction of characteristic needle lesions consistent with those from which the pathogen was most consistently isolated from field samples expressing the disease. Re-isolation of the pathogen from these lesions fulfilled Koch's postulates for red needle cast. Several successive inoculation studies were carried out to identify conditions for successful inoculation (data not shown) and over-night immersion of the whole needle fascicle in a suspension of zoospores was found to be essential for successful inoculation and reproduction of disease symptoms. This reflects the observations of the disease in the field in which lesions are most commonly observed at the base of the needle fascicle following periods of consistent rainfall and high humidity. Despite our efforts to optimise inoculation, the level of infection remained variable between Pinus radiata clones and Phytophthora pluvialis isolates. These observations are consistent with the infection of Pinus radiata by Phytophthora pinifolia as reported by Ahumada et al. (2013) and additional controlled inoculation studies which we have carried out using Phytophthora

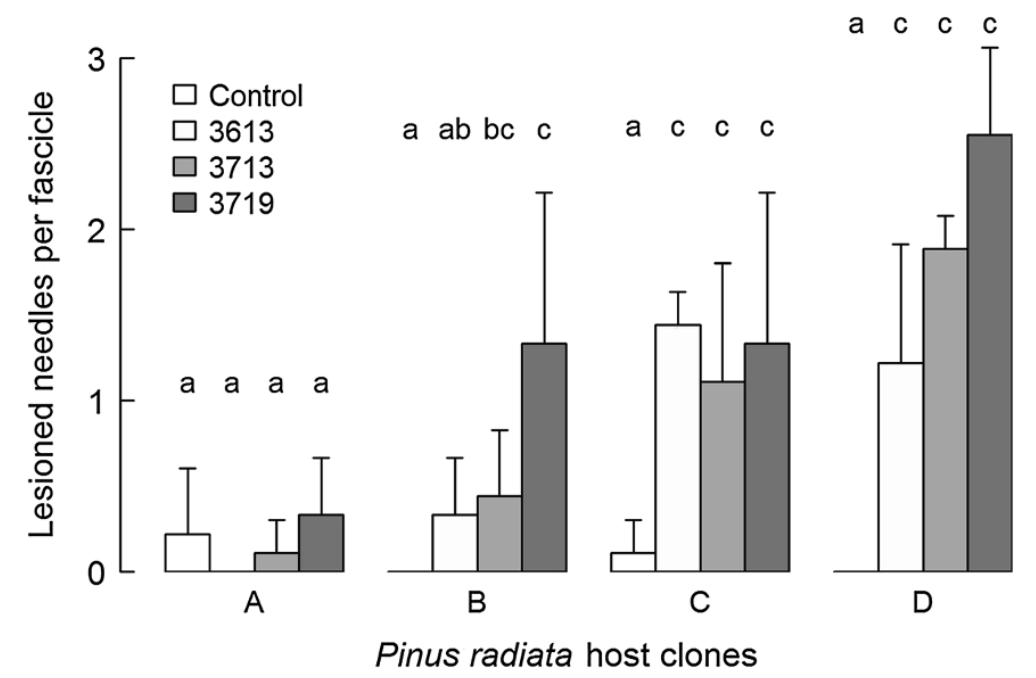

Figure 10 Average number of needles with lesions per fascicle from 4 clonal Pinus radiata host trees (A, B, C, D) each inoculated with 3 Phytophthora pluvialis isolates NZFS isolates $\mathbf{3 6 1 3}, \mathbf{3 7 1 3}, \mathbf{3 7 1 9}$ or left uninoculated (control). Means $\pm \mathrm{SE}, n=3$ blocks. Different lower case letters indicate significant differences at $a=0.05$ using comparisons of nested models (separate vs. merged factor levels) based on likelihood ratio tests. 
kernoviae (data not shown). Our future work focussing on improving the understanding of the environmental and host factors governing infection in the field should help in the development of improved inoculation procedures and contribute to understanding the susceptibility of Pinus radiata to foliar infection by Phytophthora species in general.

Phytophthora kernoviae, a species known to have been present in New Zealand since at least the 1950s (Ramsfield et al. 2007) was recovered from symptomatic needles comparatively rarely. Artificial inoculations of Phytophthora kernoviae demonstrate the potential for this pathogen to cause lesions on Pinus radiata. However, there is no clear evidence that needle casting can be directly attributed to Phytophthora kernoviae. Within New Zealand Pinus radiata plantations, this species has previously only been recovered from soils and occasionally from roots (Ramsfield et al. 2009). In root inoculation tests of young Pinus radiata seedlings, Phytophthora kernoviae caused some root mortality but infections were not lethal and the root systems would have been considered healthy in the absence of uninoculated controls for comparison (Ramsfield et al. 2009). This species has been identified in association with red needle cast but not as consistently as Phytophthora pluvialis across the geographic range of red needle cast symptoms. Furthermore, soil-based recoveries of Phytophthora kernoviae in previous studies have not been associated with needle disease. The possible role of Phytophthora kernoviae as a foliar pathogen of Pinus radiata is under current investigation and will be reported in a subsequent publication. Phytophthora kernoviae was first recorded on fruit, shoots and foliage of Annona cherimola Miller in Northland in 2002 (Ramsfield et al. 2009), and has subsequently been isolated occasionally from Rhododendron spp. with minor foliage necrosis and dieback and once from the dying lower foliage of a native podocarp Prumnopitys ferruginea (D. Don) de Laub. (New Zealand Forest Research Institute Forest Health Database, Scion, unpublished records). There is, however, little evidence supporting Phytophthora kernoviae as the primary cause of red needle cast based on observations in the field and laboratory, and on rates of recovery from affected needles.

Red needle cast has been recorded at a number of discrete sites predominantly in damp and/or elevated locations in the North Island of New Zealand and also in the north of the South Island. However, significant areas of the forest estate remain unaffected by the disease. Sites where symptoms have been frequently recorded, and where they are most severe, are typically prone to mist and fog, and hence to prolonged periods of needle wetness. Such sites are commonly at elevations greater than $500 \mathrm{~m}$ such as plateaus or ridge tops. Sites at lower elevations have different (lower) moisture conditions that result in reduced incidence and severity of red needle cast symptoms or their complete absence. At many sites, only the lower foliage has been affected and this feature, coupled with the seasonal onset of the disease during late autumn and winter when tree growth is negligible, may mean that tree growth will be largely unaffected. At the rare sites where disease levels have been severe during consecutive years there will be increment loss. The extent of this loss is currently being evaluated at a range of sites around the country. The findings presented here suggest the existence of clonal variation in host susceptibility to Phytophthora pluvialis/red needle cast (Table 1, Figure 9). This has been corroborated by a clonal field trial in New Zealand (Dungey et al., in preparation) which indicates that breeding efforts and careful selection of radiata clones selection can reduce the risk of red needle cast and thus limit economic losses from future pine plantations in New Zealand. This aspect will be further examined and selections of resistant lines employed in those sites where climatic conditions result in consistently high disease levels.

The association of Phytophthora pluvialis with red needle cast reflects the aetiology of the disease. The onset of red needle cast is observed during late autumn or winter in areas exposed to prolonged periods of wet conditions. This is consistent with reports for other forest Phytophthora species affecting leaves and needles including Phytophthora pinifolia on Pinus radiata and Phytophthora ramorum (Durán et al. 2008; Werres et al. 2001). Each of these diseases has been associated with needle wetness with observations made in areas favouring prolonged periods of canopy wetness. Climatic associations with red needle cast are under investigation and will be reported in due course.

Our observations from field samples and controlled inoculation studies have been that very similar early needle symptoms can be produced by Phytophthora pluvialis and Phytophthora kernoviae to those reported for Phytophthora pinifolia infecting Pinus radiata in Chile (Ahumada et al. 2013; Durán et al. 2008). These observations may indicate a consistent response to Phytophthora spp. infection within Pinus radiata and that given the right environmental conditions, Pinus radiata may be susceptible to a broad range of Phytophthora species. The black resinous marks that form on green needles (Figure 1) and within the pale-olive lesions (Figures 2 and 3) are identical though not always observed in infection by Phytophthora pluvialis. The symptoms of the Phytophthora pinifolia induced disease Daňo Foliar del Pino in Chile are most likely to appear on needles in early winter. In New Zealand, however, the initial appearance of red needle cast symptoms has been observed to vary with location and year, ranging from late autumn to spring. There are also other differences between the two diseases. Phytophthora pinifolia is reported to cause lesions and resin bleeding of the branches, initiating at the base of the needle fascicle (Durán et al. 2008). Shoots of young trees wilt and die as a result of this infection. Lesions in branches and stems may 
coalesce to form cankers with possible girdling and death of young trees. Branch and stem infection has not been observed in New Zealand in association with Phytophthora pluvialis. The age range of affected Pinus radiata is also different. While young trees, between the ages of 1-4 have been affected in Chile, with mortality common, trees in this age class are rarely affected in New Zealand. In both cases disease in young trees has been in close proximity to badly diseased older stands. There have been no reports of establishment failures associated with red needle cast. There is insufficient knowledge to comment conclusively on the seasonal expression of Phytophthora kernoviae in the field at this time.

Phytophthora pluvialis is a member of Phytophthora Clade 3 (Cooke et al. 2000). Other members of this clade (including Phytophthora nemorosa E. M. Hansen and Reeser, Phytophthora pseudosyringae T. Jung \& Delatour, and Phytophthora ilicis Buddenhagen \& R.A. Young) are typically associated with infection of leaves, shoots, and stems in north-western America (Buddenhagen and Young 1957; Hansen et al. 2003; Wickland et al. 2008). To date, Phytophthora pluvialis has been isolated from environmental samples and has been rarely associated with twig and stem cankers on tanoak within forests of south-western Oregon where it is believed to be endemic (Reeser 2013). These forests are dominated by Douglas-fir (Pseudotsuga menziesii (Mirb.) Franco) and tanoak (Lithocarpus densiflorus (Hook. \& Arn.) Rehder). Recovery of Phytophthora nemorosa, Phytophthora pseudosyringae, Phytophthora psychrophila T. Jung \& E.M. Hansen and Phytophthora pluvialis in environmental canopy drip samples within these forests (Reeser et al. 2011) is indicative of leaf and or needle infection by these species. However, no direct association between Phytophthora pluvialis and leaf/needle symptoms have been reported within Oregon forests. There have been no previous reports of red needle cast from the endemic range of Pinus radiata. This is the first report of Phytophthora pluvialis causing significant levels of disease and the first in exotic Pinus radiata plantations.

The discovery of another aerially dispersed Phytophthora sp. causing a disease of Pinus radiata further extends the number of new aerial Phytophthora spp. known to affect coniferous tree species. Other combinations include Phytophthora pinifolia on Pinus radiata and Phytophthora ramorum on Larix spp., Sequoia sempervirens (D.Don) Endl., Pseudotsuga menziesii and other conifer species (Brasier and Webber 2010). These aerially dispersed pathogens present new challenges to forest managers due to their rapid dispersal across the landscape and impact on ecological and economic significant tree species.

Preliminary studies of the level of diversity in the isolates collected in the last four years, and comparison with the diversity in Oregon isolates (Reeser et al. 2013) point to Phytophthora pluvialis being a relatively recent introduction to New Zealand. Further investigation into the genetic diversity and virulence of Phytophthora pluvialis isolates across the New Zealand population is currently underway. However, the method of introduction can only be speculated upon. Field-based observations have indicated that the pathogen infects only the needle blade with shed needles, rain splash and air movement being the most likely drivers of pathogen movement. The potential for subsequent spread of the pathogen through the trade of export logs has been demonstrated to be negligible (Hood et al. 2014). These findings are consistent to those made for Phytophthora pinifolia on Pinus radiata by Ahumada et al. (2012) who similarly concluded that there was no evidence of pathogens surviving on sawn green timber.

Populations of Phytophthora pluvialis would probably have taken some seasons to build up to levels where disease was noticeable. Therefore, it is likely that an incursion occurred some years prior to the first records of olive needle lesions with black resinous marks (now clearly associated with infection by this pathogen) in 2008. This would particularly be the case in locations where disease levels are regularly low due to climatic constraints and do not occur in every season. For those discrete locations where disease levels have been consistently high over the past four years there may be potential to employ Pinus radiata breeding lines with high resistance to disease development.

\section{Conclusions}

Phytophthora pluvialis is the most consistently isolated pathogen associated with red needle cast of Pinus radiata in New Zealand. Controlled inoculation studies, including the reproduction of needle lesions, needle cast and fulfilment of Koch's postulates have provided further evidence that it is the primary cause of red needle cast. Phytophthora kernoviae was also recovered from symptomatic needles sourced from field sites relatively rarely. The extended history of Phytophthora kernoviae in New Zealand with no recognised association to red needle cast symptoms indicates this is not the primary cause of the disease. Recovery of both species from needle lesions along with reports of Phytophthora pinifolia in Chile indicate a consistent response to Phytophthora spp. infection within Pinus radiata. Furthermore, that given the right environmental conditions, Pinus radiata needles may be susceptible to infection by a broad range of Phytophthora species.

\section{Competing interests}

The authors declare that they have no competing interests.

\section{Authors' contributions}

Disease occurrence and analysis of symptom development in the field was collated across field work and diagnostic analyses performed by MD, JG and NW with analysis by LB. MD, NW and JG undertook the plant inoculation studies. MB carried out the statistical analyses. The paper was written by MD and NW, assisted by LB. All authors read and approved the final manuscript. 


\section{Acknowledgements}

The following are thanked for their technical or specialist assistance: Heather Flint, Rebecca McDougal, Rita Tetenburg, Mitchell West and Liam Wright. We thank Ruth McConnochie of the Radiata Pine Breeding Company for the supply of plants for experimental work. We are also grateful for discussion and advice to: lan Hood, Bill Dyck, Beccy Ganley, George Gill, Wellcome Ho, Paul Stevens, Ivan Veljkovic, and Wei-Young Wang. Funding was provided by the New Zealand Forest Owners' Association and the New Zealand Ministry of Business, Innovation, and Employment.

Received: 12 March 2013 Accepted: 17 February 2014

Published online: 23 May 2014

\section{References}

Ahumada, R, Rotella, A, Slippers, B, \& Wingfield, M. (2013). Pathogenicity and sporulation of Phytophthora pinifolia on Pinus radiata in Chile. Australasian Plant Pathology, 42(4), 413-420. doi:10.1007/s13313-013-0212-4.

Bain, J, Sopow, SL, \& Bulman, LS. (2012). The sirex woodwasp in New Zealand: history and current status. In B Slippers, P de Groot, MJ Wingfield (Eds.), The Sirex Woodwasp and its Fungal Symbiont: Research and Management of a Worldwide Invasive Pest, (Vol. XII). New York: Springer.

Benjamini, Y, \& Hochberg, Y. (1995). Controlling the false discovery rate: a practical and powerful approach to multiple testing. Journal of the Royal Statistical Society Series B, 57, 289-300.

Brasier, CM. (2008). The biosecurity threat to the UK and global environment from international trade in plants. Plant Pathology, 57(5), 792-808. doi:10.1111/j.1365-3059.2008.01886.x.

Brasier, C, \& Webber, J. (2010). Sudden larch death. Nature, 466, 824-825.

Buddenhagen, IW, \& Young, RA. (1957). A leaf and twig disease of English holly caused by Phytophthora ilicis n.sp. Phytopathology, 47, 95-101.

Bulman, L, Dick, M, Ganley, R, McDougal, R, Schwelm, A, \& Bradshaw, R. (2013). Dothistroma needle blight. In G Nicolotti \& P Gonthier (Eds.), Infectious forest diseases. Wallingford, UK: CABI. In Press.

Cooke, DE, Drenth, A, Duncan, JM, Wagels, G, \& Brasier, CM. (2000). A molecular phylogeny of Phytophthora and related oomycetes. Fungal Genetics and Biology, 30(1), 17-32. doi:10.1006/fgbi.2000.1202.

Core Team, R. (2012). R: A language and environment for statistical computing. Vienna, Austria: Foundation for Statistical Computing.

Durán, A, Gryzenhout, M, Slippers, B, Ahumada, R, Rotella, A, Flores, F, Wingfield, BD, \& Wingfield, MJ. (2008). Phytophthora pinifolia sp nov associated with a serious needle disease of Pinus radiata in Chile. Plant Pathology, 57(4), 715-727. doi:10.1111/j.1365-3059.2008.01893.x.

Durán, A, Gryzenhout, M, Drenth, A, Slippers, B, Ahumada, R, Wingfield, BD, \& Wingfield, MJ. (2010). AFLP analysis reveals a clonal population of Phytophthora pinifolia in Chile. Fungal Biology, 114(9), 746-752. doi:10.1016/j.funbio.2010.06.008.

Erwin, DC, \& Ribeiro, OK. (1996). Phytophthora diseases worldwide. Minnesota: APS Press.

Flux, A, Gadgil, PD, Bain, J, \& Nuttal, MJ. (1993). Forest health: forest, tree and wood protection in New Zealand. New Zealand: Ministry of Forestry.

Forestry Commission (2012). Phytophthora ramorum in larch trees - update. Bristol UK: Forestry Commission. http://www.forestry.gov.uk/pramorum.

Gadgil, PD. (1984). Cyclaneusma (Naemacyclus) needle-cast of Pinus radiata in New Zealand. 1: biology of Cyclaneusma minus. New Zealand Journal of Forestry Science, 14, 179-196.

Hansen, EM, Reeser, PW, Davidson, JM, Garbelotto, M, Ivors, K, Douhan, L, \& Rizzo, DM. (2003). Phytophthora nemorosa, a new species causing cankers and leaf blight of forest trees in California and Oregon, USA. Mycotaxon, 88, 129-138.

Hood, IA, Williams, NM, Dick, MA, Arhipova, N, Kimberley, M, \& Gardner, J. (2014). Decline in vitality of propagules of Phytophthora pluvialis and Phytophthora kernoviae and their inability to contaminate or colonise bark and sapwood of Pinus radiata log segments. New Zealand Journal of Forestry Science, In Press.

Jeffers, SN, \& Martin, SB. (1986). Comparison of two media selective for Phytophthora and Pythium species. Plant Disease, 70(11), 1038-1043.

Jung, T, Nechwatal, J, Cooke, DEL, Hartmann, G, Blaschke, M, Osswald, WF, Duncan, JM, \& Delatour, C. (2003). Phytophthora pseudosyringae sp. nov., a new species causing root and collar rot of deciduous tree species in Europe. Mycological Research, 107, 772-789. doi: 10.1017/S0953756203008074.

Kershaw, DJ. (1989). History of forest health surveillance in New Zealand. New Zealand Journal of Forestry Science, 19, 375-377.
Lane, CR, Hobden, E, Walker, L, Barton, VC, Inman, AJ, Hughes, KJD, Swan, H, Colyer, A, \& Barker, I. (2007). Evaluation of a rapid diagnostic field test kit for identification of Phytophthora species, including P. ramorum and P. kernoviae at the point of inspection. Plant Pathology, 56(5), 828-835. doi:10.1111/j.1365-3059.2007.01615.x.

New Zealand Forest Owners Association (2012). New Zealand plantation forest industry facts and figures. Wellington, New Zealand: Ministry for Primary Industries.

O'Brien, PA, Williams, N, \& Hardy, GE. (2009). Detecting phytophthora. Critical Reviews in Microbiology, 35(3), 169-181.

Ramsfield, TD, Dick, MA, Beever, RE, \& Horner, IJ. (2007). Phytophthora kernoviae - of southern hemisphere origin? Asilomar, California: Paper presented at the 4th IUFRO Phytophthoras in Forests and Natural Ecosystems. 26-31 August 2007.

Ramsfield, TD, Dick, MA, Beever, RE, Horner, IJ, McAlonan, MJ, \& Hill, CF. (2009). Phytophthora kernoviae in New Zealand. Monterey, California: Paper presented at the Phytophthoras in Forests and Natural Ecosystems. Proceedings of the Fourth Meeting of the International Union of Forest Research Organizations (IUFRO) Working Party S07.02.09. August 26-31.

Reeser, P, Sutton, W, \& Hansen, E. (2011). Phytophthora species in tanoak trees, canopydrip, soil, and streams in the sudden oak death epidemic area of south-western Oregon, USA. New Zealand Journal of Forestry Science, 41S, S65-S73.

Reeser, P, Sutton, W, \& Hansen, E. (2013). Phytophthora pluvialis, a new species found in mixed tanoak-Douglas-fir forests of western Oregon, U.S.A. North American Fungi, 8(7), 1-8.

Santini, A, Ghelardini, L, De Pace, C, Desprez-Loustau, M, Capretti, P, Chandelier, A, Cech, T, Chira, D, Diamandis, S, Gaitniekis, T, Hantula, J, Holdenrieder, O, Jankovsky, L, Jung, T, Jurc, D, Kirisits, T, Kunca, A, Lygis, V, Malecka, M, Marcais, B, Schmitz, S, Schumacher, J, Solheim, H, Solla, A, Szabo, I, Tsopelas, P, Vannini, A, Vettraino, AM, Webber, J, Woodward, S, \& Stenlid, J. (2012). Biogeographical patterns and determinants of invasion by forest pathogens in Europe. New Phytologist, 197, 238-250.

Werres, S, Marwitz, R, Man In't veld, WA, De Cock, AWAM, Bonants, PJM, De Weerdt, M, Themann, K, llieva, E, \& Baayen, RP. (2001). Phytophthora ramorum sp. nov., a new pathogen on Rhododendron and Viburnum. Mycological Research, 105(10), 1155-1165. doi:10.1016/s0953-7562(08)61986-3.

Wickland, AC, Jensen, CE, \& Rizzo, DM. (2008). Geographic distribution, disease symptoms and pathogenicity of Phytophthora nemorosa and Phytophthora pseudosyringae in California, USA. Forest Pathology, 38(4), 288-298. doi:10.1111/j.1439-0329.2008.00552.x.

Zuur, AF, Leno, EN, Walker, N, Saveliev, AA, \& Smith, GM. (2009). Mixed effects models and extensions in ecology with R. New York: Springer.

doi:10.1186/s40490-014-0006-7

Cite this article as: Dick et al:: Pathogenicity of Phytophthora pluvialis to Pinus radiata and its relation with red needle cast disease in New

Zealand. New Zealand Journal of Forestry Science 2014 44:6.

\section{Submit your manuscript to a SpringerOpen ${ }^{\odot}$ journal and benefit from:}

- Convenient online submission

Rigorous peer review

- Immediate publication on acceptance

- Open access: articles freely available online

- High visibility within the field

- Retaining the copyright to your article

Submit your next manuscript at $>$ springeropen.com 